\title{
Ichthyoplankton of Slope and Gulf Stream Waters off Nova Scotia in Late Autumn 1974
}

\author{
S. A. Evseenko \\ All-Union Research Institute of Marine Fisheries and Oceanography (VNIRO) \\ 17 V. Krasnoselskaya, Moscow, USSR
}

\begin{abstract}
Ichthyoplankton, collected in the Gulf Stream frontal zone off Nova Scotia in late autumn 1974, was represented by 22 families. The larvae of some species of these families have not been previously found in the area. Myctophid larvae were the most abundant and were represented in many samples. Zoogeographical structure of the ichthyoplankton community and the larval distribution of some groups are briefly discussed.
\end{abstract}

\section{Introduction}

The study of ichthyoplankton in the Gulf Stream is of great interest, because data on the species composition and distribution of the ichthyofauna allow evaluation of the effects of the Gulf Stream on the dispersal of eggs and larvae of shelf and oceanic fishes with respect to drift rates away from the areas inhabited by the adult populations. Such information is useful in assessing peculiarities of recruitment to populations which live on the continental shelf and slope adjacent to the Gulf Stream in the western North Atlantic. The Gulf Stream has been shown to be a transporter of eggs, larvae and juveniles of some fish species whose entire life cycle is primarily associated with shelf waters (neritic species) and other shelf species whose initial stages of development occur in oceanic waters (nerito-oceanic species) (Anderson, 1957; Berry, 1959; Gehringer, 1959; Caldwell, 1962; Smith et al., 1975; Evseenko, 1976; Powles, 1979).

A comparison of data on distribution and abundance of eggs and larvae in shallow shelf waters with those in waters associated with the Gulf Stream would allow the designation of species to an ecological group, such as neritic or nerito-oceanic. This is important in studying the population dynamics of fish populations, because the recruitment (and hence abundance) of nerito-oceanic species would be expected to fluctuate to a greater extent than that of neritic species (Evseenko, 1982).

The species composition and seasonal dynamics of Gulf Stream ichthyoplankton have not been intensively studied. Most of the available information relates only to the occurrence of the larvae of some shelf species (see authors cited above) and of some oceanic fishes (e.g. Ege, 1930; Rofen, 1966) within the influence of the Gulf Stream system. The paper by Markle et al. (1980), who reported new and rare records for the Scotian Shelf of larvae of tropical and subtropical spe- cies, is a valuable contribution to knowledge of Gulf Stream ichthyofauna. A major difficulty in studying Gulf Stream ichthyoplankton is the great diversity of tropical and subtropical forms, most of which are as yet unknown at their early stages of development. This paper presents the results of a study on ichthyoplankton in the Gulf Stream frontal zone seaward of the Scotian Shelf.

\section{Materials and Methods}

The ichthyoplankton material, which forms the basis of this paper (see Appendix), was collected during a survey of the research vessel Belogorsk in the area seaward of the Scotian Shelf from 14 November to 2 December 1974. Sampling was conducted at 70 stations (Fig. 1) with a small Bongo sampler having a mouth opening of $20.5 \mathrm{~cm}$ in diameter and a mesh size of $0.714 \mathrm{~mm}$. An oblique haul from $100 \mathrm{~m}$ to the surface

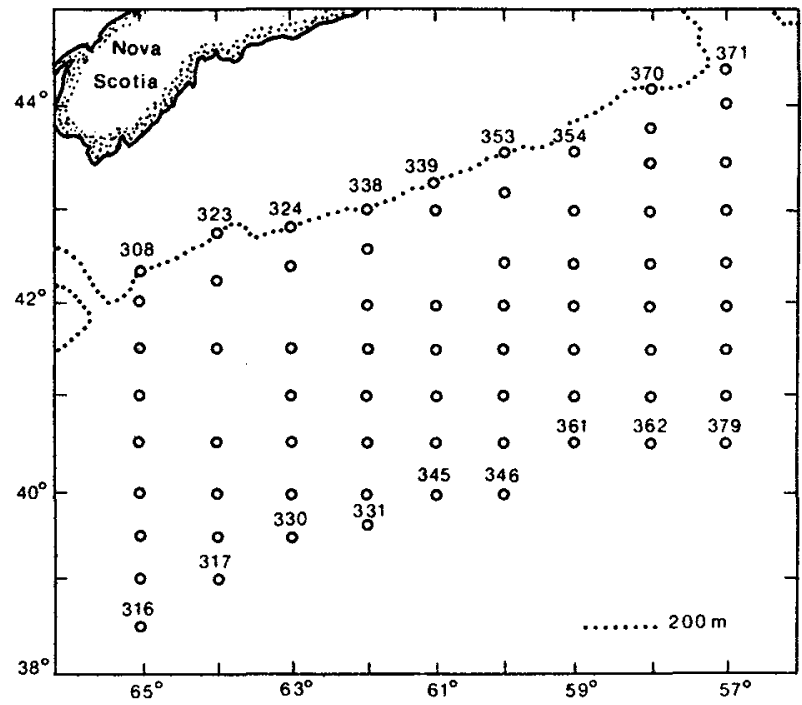

Fig. 1. Ichthyoplankton stations completed by the Belogorsk during 14 November-2 December 1974 
for 20 min was made at each station at a towing speed of approximately $3.5 \mathrm{knots}(108 \mathrm{~m} / \mathrm{min})$. The volume of water filtered during the hauls, estimated by flowmeter, ranged from 43.3 to $79.0 \mathrm{~m}^{3}$ (average $61.1 \mathrm{~m}^{3}$ ). Ichthyoplankton was found in samples taken at 31 of the stations surveyed. Data on hydrological and hydrobiological conditions during the survey were reported by Noskov et al. (MS 1977).

The samples were initially preserved in $4 \%$ formalin. In the laboratory, the eggs and larvae were later identified and the stages and phases of larval development determined by the methods proposed by Rass (1949). Larvae were stained with alizarin, according to the method of Yakubovsky (1970), to facilitate the counting of vertebrae and fin rays. The symbols used in the text for identification of the morphometric and meristic characteristics of the larvae are as follows: $T L=$ total length, $S L=$ standard length, $H L=$ head length, $P A L=$ preanal length,$B D=$ body length, and $E D=$ eye diameter. The illustrations of larvae were drawn with the aid of a Promar projecting microscope.

\section{Family Congridae}

\section{Gnathophls bathytopos Smith and Kanazawa 1977}

1 larva: $24.0 \mathrm{~mm} \mathrm{SL}$ (sta. 326)

The larva has properties characteristic of G. bathytopos described by Smith (1979), namely, the snout is elongated and pointed, there is a crescent-shaped patch of black pigment under the eye, pigment extends ventrally along the length of the gut, and 132 or 133 myomeres are evident.

\section{Family Gonostomatidae}

\section{Vinciguerria poweriae (Cocco 1838)}

2 larvae: $9.8 \mathrm{~mm}$ SL (sta. 312 ); $10.6 \mathrm{~mm} \mathrm{SL}$ (sta. 359).

Identification of the larvae was based on the description given by Ahlstrom and Counts (1958). The species is found in the eastern North Atlantic south of $43^{\circ} \mathrm{N}$ (Witzell, 1973) and has been recorded only off Bermuda and in the Gulf of Mexico in the western Central Atlantic. Grey (1964) found larvae off Bermuda. The two larvae noted above are presumably the first larvae caught so far north of the northern fringe of the Gulf Stream off the Scotian Shelf in the Northwest Atlantic.

\section{Gonostoma elongatum Günther 1878}

3 larvae: $7.0 \mathrm{~mm} \mathrm{SL}$ (sta. 317); $9.3 \mathrm{~mm} \mathrm{SL} \mathrm{(sta.} \mathrm{320);}$ $9.6 \mathrm{~mm}$ SL (sta. 315).
The specimens fit the description of the species given by Jespersen and Tåning (1926). In the western Atlantic, $G$. elongatum has been observed off the east coast of the United States $\left(41^{\circ} \mathrm{N}\right)$, near Bermuda and southward to at least the northeast coast of South America (Grey, 1964). A single specimen has been reported from the southwestern edge of the Grand Bank at $44^{\circ} 08^{\prime} \mathrm{N}, 52^{\circ} 50^{\prime} \mathrm{W}$ (Leim and Scott, 1966). Larvae have been found off Florida, eastward to the Leeward Islands in the western Central Atlantic (Grey, 1964) and on Georges Bank in the Northwest Atlantic (Joakimsson, MS 1978). The three specimens noted above are the first larvae of the species caught off the Scotian Shelf.

\section{Cyclothone braueri Jespersen and Tåning 1926}

1 juvenile: $18.0 \mathrm{~mm} \mathrm{SL} \mathrm{(sta.} \mathrm{329).}$

This species is widely distributed in the Atlantic and has been observed in the western Atlantic from $65^{\circ} \mathrm{N}$ in Davis Strait southward to $43^{\circ} \mathrm{S}$ (Mukhacheva, 1974).

\section{Family Sternoptychidae}

\section{Sternoptyx diaphana Hermann 1781}

1 larva at metamorphic stage: $7.4 \mathrm{~mm} \mathrm{SL}$ (sta. 310 ).

Identification of this specimen was based on information in the paper by Badcock and Baird (1980). The most northern records of S. diaphana in the Northwest Atlantic were specimens taken near LaHave Bank on the Scotian Shelf $\left(42^{\circ} 46^{\prime} \mathrm{N}, 63^{\circ} 22^{\prime} \mathrm{W}\right.$ ) (Schultz, 1961). The larva noted above was caught near the northern limit of the distribution of the species in the western North Atlantic.

\section{Family Melanostomiatidae}

\section{Genus ? Species ?}

1 larva: $9.1 \mathrm{~mm} \mathrm{SL} \mathrm{(sta.} \mathrm{333).}$

The body is long, narrow and slightly compressed laterally. The head is long and the upper profile of the snout is slightly concave. There are 7 teeth on the premaxillary, 10 teeth on the maxillary and 17 teeth on the dentary. The teeth 2-3, 4-5, 6-7 and 9-10 on the upper jaw are doubled. The pectoral fins are located near the ventral margin of the trunk. The number of myomeres is 66 . The anus is located at the level of myomere 60 . The end of the anal fin is located at myomere 64 . The urostyle is curved. The formation of 12-13 dorsal and 14-15 anal fin rays is evident. The first ray of the anal fin is located at the level of the fifth ray of the dorsal fin. Dorsal and ventro-lateral rows of melanophores are distributed along both sides of the body. 
The dorsal row, consisting of large stellate melanophores (one for each myomere), begins over the medulla oblongata and extends to the urostyle. The ventro-lateral row consists of pigment stripes, extending along the myosepta of myomeres 4-64, each stripe being formed usually by 3-4 (seldom 2) melanophores. Groups of small melanophores are also present on other parts of the body, particularly in the folds of the dorsal fin, on the gut and rectum and on the throat.

The larvae of most of the Melanostomiatidae species are not yet known, and their identification even to the generic level is difficult. It can only be noted that the character of the pigmentation on the captured larva (presence of dorsal and ventro-lateral rows of melanophores, and the configuration, size and location of the pigment cells in these rows) coincides with the description given by Beebe and Crane (1939) for a 25-mm SL specimen of Echiostoma barbatum (= E. tanneri).

\section{Family Chauliodontidae}

\section{Chaullodus sloani Bloch and Schneider 1801}

1 larva: $25.0 \mathrm{~mm} \mathrm{SL}$ (sta. 320 )

Identification of the specimen is based on the description of Belyanina (1977). This species is widely distributed in tropical and temperate waters of the world's oceans. In the Northwest Atlantic, it has been reported from various parts of the Grand Bank as far north as $48^{\circ} \mathrm{N}$ and from the Laurentian Channel near St. Pierre Bank (Leim and Scott, 1966), and larvae have been recorded from the open areas of the western North Atlantic (Belyanina, 1977).

\section{Family Synodontidae}

\section{Trachinocephalus myops (Forster 1801)}

1 larva: $19.7 \mathrm{~mm} \mathrm{SL}$ (sta. 343).

The body is very elongated and slightly compressed laterally (Fig. 2). The preanal part of the body is much longer than the postanal section (PAL $=74.6 \%$ $\mathrm{SL})$. The head is relatively small ( $\mathrm{HL}=11.7 \% \mathrm{SL})$ but the eyes are quite large $(E D=37.0 \% \mathrm{HL})$. The angle of the mouth extends posteriorly to a point below the middle of the eye. There are 6 teeth on either side of the upper and lower jaws. The anal fin has 13 pterygiophores and the caudal fin has 18 rays. Pectoral fin rays were not fully formed. The number of myomeres (56) corres-

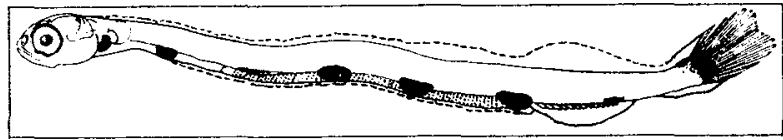

Fig. 2. Trachinocephalus myops larva, $19.7 \mathrm{~mm} \mathrm{SL}$ (Station 343). ponds to that of vertebrae, there being 39 in the preanal and 17 in the postanal parts of the body. Six large pigment spots lie at regular intervals along both sides of the body between the head and the anus (the third one being damaged), and a very large melanophore is located near the posterior end of the anal fin. The locations of the pigment spots (except the first one near the base of the pectoral), relative to the myomeres are as follows: the second spot is at the level of myomeres $6-8$, the third spot at myomeres $12-14$, the fourth spot at myomeres 19-23, the fifth spot at myomeres 26-28 and the sixth spot at myomeres 34-38. The large melanophore near the posterior part of the anal fin is at the level of myomeres 44-46. In addition, a stellate melanophore lies over each hemisphere of the midbrain on the top of the head, and the bases of rays 1-16 of the caudal fin and the adjacent part of the caudal peduncle are pigmented intensively by small melanophores, forming a crescent-shaped band.

The identification of Synodontidae larvae is difficult before the pectoral and anal fins are completely formed. The primary features of the larva described above (i.e. 6 preanal spots, 56 vertebrae, and rudiments of more than 12 anal-fin rays) are characteristic of larvae of both Synodus foetens (L.) and T. myops (Forster). However, according to Mansueti and Hardy (1967), larvae of $S$. foetens have no melanophores on their occiput and the lobe of the caudal fin has different pigmentation. Therefore, this larva is considered to be T. myops. Moreover, its features correspond to the description of larvae of this species from the Central Atlantic (Rudomyetkina, 1980).

T. myops is widely distributed in tropical waters of the world's oceans. In the western North Atlantic, the species has been found northward to Cape Cod (Anderson et al., 1966), and juveniles have been reported from the Scotian Shelf (Markle et al., 1980), presumably carried there by incursions of Gulf Stream water.

\section{Family Notosudidae}

\section{Scopelosaurus sp.}

1 larva: $17.8 \mathrm{~mm} \mathrm{SL}$ (sta. 374 ).

The body is long, narrow and slightly compressed laterally. There are 55 vertebrae, 13 preanal, 22 from the anus to the origin of the anal fin, and 20 from the origin of the anal fin to the urostyle. The anal fin has 15 rays, and the caudal fin has 20 rays, one being much less developed than the others. Rays were not formed in the other fins. There is no pigmentation on the body except in the caudal region (Fig. 3), where several small stellate melanophores are located in the middle part of rays 9-11 and one is seen on the upper fleshly lobe of the caudal fin. 


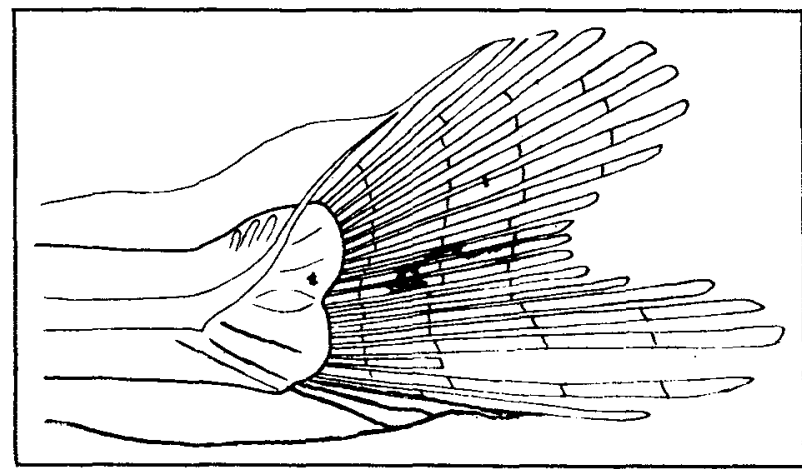

Fig. 3. Caudal fin of Scopelosaurus sp. larva, $17.8 \mathrm{~mm} \mathrm{SL} \mathrm{(Station}$ 374).

Four species of the genus Scopelosaurus inhabit the waters of the western North Atlantic, namely $S$. mauli, S. smithii, S. lepidus and S. argenteus, whose larvae have been described by Bertelsen et al. (1976). The larvae described above differs from the larvae of the first three species by the character of its caudal pigmentation. It is somewhat similar to $S$. argenteus by the presence of one pigment spot on the peduncle of the caudal fin, but larvae of $S$. argenteus have no pigment on the rays of the caudal fin. Therefore, the species name of the larva described above is presently uncertain.

\section{Scopelosaurus mauli Bertelsen, Krefft and Marshall 1976}

7 larvae: $6.5 \mathrm{~mm}, 11.0 \mathrm{~mm}, 18.5 \mathrm{~mm} \mathrm{SL}$ (sta. 334); $7.5 \mathrm{~mm} \mathrm{SL}$ (sta. 335); $10.7 \mathrm{~mm} \mathrm{SL}$ (sta. 320); 11.7 mm SL (sta. 333); $12.6 \mathrm{~mm} \mathrm{SL} \mathrm{(sta.} \mathrm{377).}$

This species is found in tropical and subtropical waters of the western Atlantic, being most abundant between $10^{\circ} \mathrm{N}$ and $40^{\circ} \mathrm{N}$ (Bertelsen et al., 1976). The larvae, noted above, were caught between $40^{\circ} 30^{\prime} \mathrm{N}$ and $41^{\circ} 30^{\prime} \mathrm{N}$ near the northern limit of the distribution of the species in the western North Atlantic.

\section{Family Myctophidae}

\section{Hygophum macrochir (Guinther 1864)}

1 larvae: $5.7 \mathrm{~mm} \mathrm{SL} \mathrm{(sta.} \mathrm{317).}$

Identification of this species was based on the description by Moser and AhIstrom (1974). H. macrochir is a tropical species, which is more numerous in the eastern than in the western waters of the Atlantic. Data given by Nafpaktitis et al. (1977) indicate that this species has not been reported north of the Bahama Islands in the western North Atlantic. Larval distribution in the Atlantic is unknown, but the specimen noted above was caught far north of the range of the adult habitat.

\section{Hygophum hygoml (Lütken 1892)}

8 larvae: $4.2 \mathrm{~mm}, 8.5 \mathrm{~mm} \mathrm{SL}$ (sta. 333 ); $3.5 \mathrm{~mm}, 4.0$ $\mathrm{mm} \mathrm{SL} \mathrm{(sta.} \mathrm{335);} 4.8 \mathrm{~mm} \mathrm{SL}$ (sta. 343); $5.3 \mathrm{~mm} \mathrm{SL}$ (sta. 330); $5.5 \mathrm{~mm} \mathrm{SL}$ (sta. 317 ); $6.4 \mathrm{~mm} \mathrm{SL} \mathrm{(sta.}$ 360).

Larvae of this species were first described by Tåning (1918). Data on morphology of larvae have been reported by Moser and Ahlstrom (1974) and PertsevaOstroumova (1974). H. hygomi is a semi-subtropical species (Nafpaktitis et al., 1977), but there is no information on distribution of its larvae in the western North Atlantic. The 8 larvae noted above were caught near the northern limit of the distribution range of the species.

\section{Hygophum reinhardtI (Luitken 1892)}

1 juvenile: $24.5 \mathrm{~mm} \mathrm{SL}$ (sta. 359).

The species is an inhabitant of tropical and subtropical waters (Nafpaktitis et al., 1977). The juvenile captured off the Scotian Shelf is apparently a northern range record for the species in the western North Atlantic.

\section{Benthosema glaciale (Reinhardt 1837)}

2 juveniles: $13.0 \mathrm{~mm} \mathrm{SL}$ (sta. 333); $22.0 \mathrm{~mm} \mathrm{SL} \mathrm{(sta.}$ 352).

This is a subpolar-temperate species and is probably the most abundant of the North Atlantic myctophids (Nafpaktitis et al., 1977).

\section{Diogenichthys atlanticus (Tåning 1928)}

2 larvae: $4.9 \mathrm{~mm} \mathrm{SL} \mathrm{(sta.} \mathrm{377);} 8.5 \mathrm{~mm} \mathrm{SL}$ (sta. 330); 1 juvenile: $21.5 \mathrm{~mm} \mathrm{SL}$ (sta. 311 ).

Larvae of this species have been described in detail by Moser and Ahlstrom (1970). It is common in the Northwest Atlantic but is unevenly distributed in subtropical and tropical regions (Nafpaktitis et al., 1977). There is no information on distribution of larvae in the Northwest Atlantic. The specimens noted above were caught in the northern part of the range of the species in the western North Atlantic.

\section{Myctophum nitidulum Garman 1899}

1 larva: $6.7 \mathrm{~mm} \mathrm{SL} \mathrm{(sta.} \mathrm{318).}$

Identification of this larva was based on the description by Moser and Ahlstrom (1970). The species inhabits tropical and subtropical waters (Nafpaktitis et al., 1977) and it occurs south of Nova Scotia in the Northwest Atlantic. Larvae have previously been found in the vicinity of Georges Bank (Joakimsson, MS 1978). 


\section{Myctophum selenops Tåning 1928 ?}

1 larva: $9.7 \mathrm{~mm} \mathrm{SL}$ (sta. 334).

The body of this larva (Fig. 4 ) is deep (BD $=28.9 \%$ $\mathrm{SL}$ ) and the head is large (HL $=33.0 \% \mathrm{SL})$. The upper profile of the head is slightly concave. The eye has a conical mass of pigmented choroid tissue. The mouth is large with conical teeth. There are 12 large teeth on each side of the upper jaw and 16 smaller teeth on each side of the lower jaw, with teeth $3,4,6$ and 12 from the symphysis of the lower jaw being larger than the others. The length of the maxillary is $62.5 \% \mathrm{HL}$. The preanal length is $63.0 \% \mathrm{SL}$. All fins are completely formed, the number of rays being dorsal 14 , anal 18 , pectoral 17 and ventral 8 . The first ray of the dorsal fin is much shorter than the others and the last two are very close together. The anal fin begins in line with rays 8-9 of the dorsal fin. There are 33 rays in the caudal fin ( 19 principal, 7 superior procurrent and 7 inferior procurrent). There are 34 vertebrae, 13 being preanal and 21 postanal. Pigment occurs only on the head and the pectoral fins. A row of small melanophores is located on the anterior part of the upper jaw, 5 on the left side and 6 on the right. Other melanophores occur on the forward part of the head over the eye, one is found on the upper jaw in front of the choroid tissue of the eye, one above the posterior end of the upper jaw, and three on the gill cover, the upper one being branched. A large melanophore is located on the lobe of the pectoral fin, and smaller ones are present at the bases of most pectoral fin rays.

Larvae from the Indian and Pacific oceans identical to the above-noted specimen were described by Pertseva-Ostroumova (1974) and referred to as Gonichthys barnesi Whitley (?), but such identification by these authors is erroneous because these larvae have 34-36 vertebrae, in contrast to 40-41 vertebrae in species of the genus Gonichthys, and should tentatively be referred to $M$. selenops. Furthermore, Pertseva-Ostroumova (1974) also described Myctophum selenops (?) larvae from the Indian and Pacific oceans, and, judging from the data of Moser and Ahlstrom (1974), their larvae should be related to Myctophum obtusirostre. The $9.7 \mathrm{~mm}$ larva described above is very similar to those of $M$. selenops described by Moser and Ahlstrom (1974), but, because there are

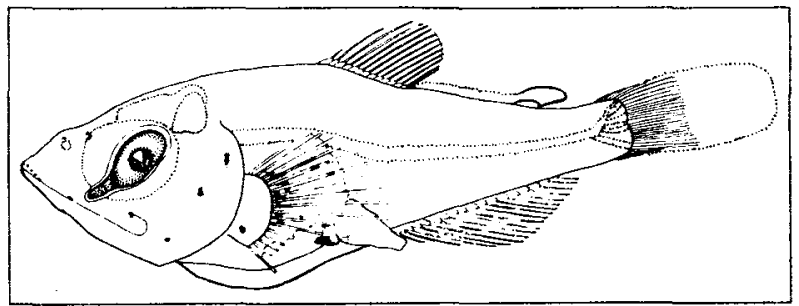

Fig. 4. Myctophum selenops (?) larva, $9.7 \mathrm{~mm}$ SL (Station 334). differences in the pigmentation of the jaws, the larva is only tentatively referred to this species.

\section{Notolychnus valdiviae (Brauer 1904)}

1 juvenile: $13.9 \mathrm{~mm} \mathrm{SL} \mathrm{(sta.} 378$ ).

This species is distributed in tropical and subtropical waters, and, according to Nafpaktitis et al. (1977), it has been recorded in the Gulf Stream off eastern Canada.

\section{Diaphus raflnesquil (Cocco 1838)}

3 larvae: $4.7 \mathrm{~mm} \mathrm{SL}$ (sta. 315); $5.5 \mathrm{~mm} \mathrm{SL} \mathrm{(sta.} \mathrm{335);}$ $5.6 \mathrm{~mm}$ SL (sta. 320).

The larvae of this species were described by Tåning (1918). Although this species is widely distributed in the North Atlantic between $20^{\circ} \mathrm{N}$ and $50^{\circ} \mathrm{N}$ (Nafpaktitis, 1968), larvae have not been previously recorded from the area of investigation off Nova Scotia.

\section{Dlaphus sp.}

1 larva: $6.1 \mathrm{~mm} \mathrm{SL} \mathrm{(sta.} \mathrm{317).}$

The structure and pigmentation of this larva are similar to those of $D$. rafinesquii, but it differs from them by the presence of 4 melanophores (instead of 2) located parallel to the edge of the caudal lobe on the caudal fin rays.

\section{Bolinichthys indlcus (Nafpaktitis and Nafpaktitis 1969)}

1 juvenile: $13.5 \mathrm{~mm} \mathrm{SL}$ (sta. 343).

Although this species is classed as subtropical, it occurs also in significant numbers in temperate regions of the open North Atlantic (Nafpaktitis et al., 1977).

\section{Ceratoscopelus maderens/s (Lowe 1839)}

4 larvae: $7.5 \mathrm{~mm}$ SL (sta. 317 ); $7.6 \mathrm{~mm} \mathrm{SL} \mathrm{(sta.} \mathrm{323);}$ $8.1 \mathrm{~mm}, 9.7 \mathrm{~mm} \mathrm{SL}$ (sta. 320).

Larvae of this species were described by Tåning (1918). According to Nafpaktitis et al. (1977), it is a temperate and semi-subtropical species. Several specimens were found in the stomachs of Atlantic cod, Gadus morhua, caught in the Laurentian Channel off Cape Breton, Nova Scotia (Leim and Scott, 1966), and the species has been observed near Iceland at $50^{\circ} \mathrm{N}$ (Bolin, 1959). Larvae have been reported from Georges Bank (Joakimsson, MS 1978).

\section{Ceratoscopelus warmingll (Lütken 1892)}

1 juvenile: $20.7 \mathrm{~mm} \mathrm{SL}$ (sta. 360).

This species is common in tropical and subtropical waters, but it may also be found in slope waters of the 
continental shelf in the Northwest Atlantic where it is transported by warm-core Gulf Stream eddies (Nafpaktitis et al., 1977).

\section{Family Paralepididae}

\section{Notolepis rissoi krøyerl (Lütken 1892)}

3 larvae: $7.0 \mathrm{~mm} \mathrm{SL} \mathrm{(sta.} \mathrm{310);} 9.5 \mathrm{~mm} \mathrm{SL} \mathrm{(sta.} \mathrm{377);}$ $13.6 \mathrm{~mm} \mathrm{SL}$ (sta. 358).

This species is widely distributed in the North Atlantic. Larvae have been described by Ege (1930), and data on the distribution of larvae, juveniles and adults have been summarized by Rofen (1966).

\section{Family Scomberesocidae}

\section{Scomberesox saurus (Walbaum 1792)}

1 egg: $2.35 \mathrm{~mm}$ diameter (sta. 333).

This egg was in developmental stage III or IV, with the embryo covering about two-thirds of the yolk sac. Eggs and larvae of this species have been described by Nesterov and Shiganova (1976), who indicated that the northern limit of egg and larval distribution in the North Atlantic corresponds approximately with the $16.5^{\circ} \mathrm{C}$ isotherm on the surface. The occurrence of this egg at $40^{\circ} 30^{\prime} \mathrm{N}$ probably represents a northern range record for eggs of $S$. saurus. There are numerous reports of adults being caught in Canadian waters around Newfoundland and Nova Scotia (Leim and Scott, 1966).

Investigations on the biology and distribution of the species in the Northwest Atlantic were reported by Dudnik et al. (1981).

\section{Family Bregmacerotidae}

\section{Bregmaceros maclellandi Thompson 1840}

2 larvae: $4.7 \mathrm{~mm} \mathrm{SL}$ (sta. 326); $7.6 \mathrm{~mm} \mathrm{SL}$ (sta. 335).

Identification of these larvae were based on the description by Belyanina (1974). In the western North Atlantic, it is distributed northward to about $40^{\circ} \mathrm{N}$ (D'Ancona and Cavinato, 1965), but no larvae have been previously recorded from Gulf Stream waters off eastern Canada.

\section{Family Macrouridae}

\section{Genus ?-Species ?}

1 larva: $1.44 \mathrm{~mm} \mathrm{HL}$ (sta. 326).

This larva was damaged, its tail broken, and part of the ventral section of the body missing. The preanal part of the body is deep and the postanal part thin and long (Fig. 5). The anus is at the level of myomeres 10-11. There are 11-12 small teeth on each side of the upper jaw and 14 teeth on each side of the lower jaw. The right ventral fin has 6 rays, the third and fourth being longer than the others. Other fins have not yet formed. The upper part of the head and the postorbital area are covered with diffused black pigment. The dorsal part of the peritoneum is highly pigmented, and there are some pigment accumulations near the lower edge of the cleithrum and at the anterior part of the ventral fin. Three large melanophores are present near the posterior end of the body, two dorsally and one vertrally.

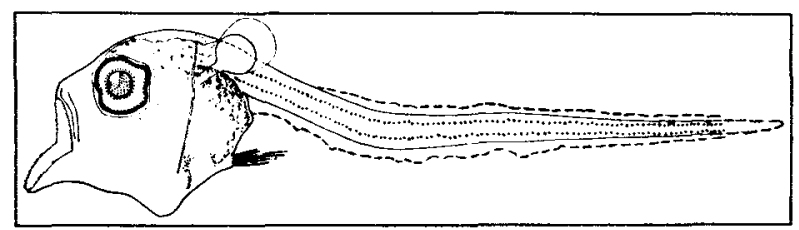

Fig. 5. Macrouridae larva, $1.44 \mathrm{~mm} \mathrm{HL}$ (Station 326).

The larva described above has 7 branchiostegal rays. The same number of rays is found in the species of 11 genera of macrourids (Marshall and Iwamoto, 1973), most of which inhabit tropical and subtropical waters. Six macrourid species have been reported from Canadian Atlantic waters (Leim and Scott, 1966). These are Trachyrhynchus murrayi, Coelorhynchus carminatus, Macrourus berglax, Coryphaenoides rupestris, Malacocephalus occidentalis, and Nezumia bairdi, but only the last two have 7 branchiostegal rays. If the larva described above resulted from spawning off Nova Scotia or the northeastern United States, it can be referred to as $M$. occidentalis or $N$. bairdi. However, this larvae has 6 ventral fin rays, whereas $M$. occidentalis has 8 rays and $N$. bairdi has 7 (rarely 6 ) rays in the ventral fin (Marshall and Iwamoto, 1973). Therefore, the larva may be referred very tenatively to $N$. bairdi.

\section{Family Scorpaenidae}

\section{Scorpaena sp. ?}

1 larva; $7.5 \mathrm{~mm} \mathrm{SL}$ (sta. 317).

Identification was difficult due to the poor condition of the larva, but, on the basis of the descriptions by Moser et al. (1977), it apparently belongs to the genus Scorpaena.

\section{Family Labridae}

\section{Genus ? Species ?}

1 larva: $5.5 \mathrm{~mm} \mathrm{SL}$ (sta. 328).

The body of this larva is deep ( $32.6 \% \mathrm{SL})$ and markedly compressed laterally (Fig. 6). The anus is 


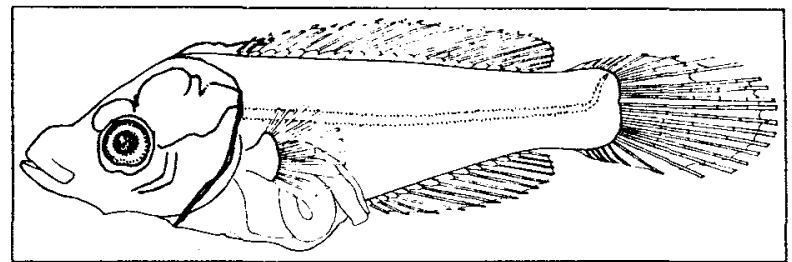

Fig. 6. Labridae larva, $5.5 \mathrm{~mm} \mathrm{SL}$ (Station 328).

situated slightly posterior to the middle of the body $(\mathrm{PAL}=59.0 \% \mathrm{SL})$. The head is large $(\mathrm{HL}=34.6 \% \mathrm{SL})$, the upper profile of the snout is concave, and the mouth is small. The dorsal and anal fins are long and contain 21 and 14 rays respectively. The pectoral fin is fan-shaped with 13 rays. Rudiments of the ventral fins are evident below the bases of the pectorals. The caudal fin has a total of 26 rays. There are 26 myomeres, 8 preanal and 18 postanal. The intestine is in the form of a loop, on top of which is the airbladder. The only melanophores present are small ones located in the membrane between the first and third rays of the dorsal fin.

Most of the Labridae inhabit subtropical and tropical waters. The early stages of their development have not been extensively studied, and identification of the larva described above is difficult even at the genus level.

\section{Family Scaridae}

\section{Genus ? Species ?}

4 larvae: $6.4 \mathrm{~mm} \mathrm{SL}$ (sta. 327 ); $7.5 \mathrm{~mm} \mathrm{SL}$ (sta. 310); $8.1 \mathrm{~mm} \mathrm{SL}$ (sta. 333); $8.3 \mathrm{~mm} \mathrm{SL} \mathrm{(sta.} \mathrm{330).}$

The body is compressed laterally (Fig. 7) but it is not deep $(\mathrm{BD}=17.3 \% \mathrm{SL})$. The anus is located approximately in the middle of the body (PAL $=52.0 \% \mathrm{SL}$ ). The head is small $(\mathrm{HL}=24.0 \% \mathrm{SL}$ ), the tip of the lower jaw extends forward, and the eyes are oval-shaped $(0.35 \times$ $0.55 \mathrm{~mm}$ ). Underlying the eye is a mass of choroid tissue pigmented by branched melanophores. The dorsal fin is long with 10 spines and 9 soft rays. The anal fin has 2 spines followed by 11 rays. The last ray of the anal fin is in line with the last ray of the dorsal fin. There are 27 rays in the caudal fin, 14 of them being principal rays. The pectoral fin has 12 rays. There are 25 vertebrae, 9 preanal and 16 postanal. The intestine is slightly curved, and the very short rectum extends to the anus almost perpendicular to the intestine. A small airbladder is located in the body cavity over the posterior end of the intestine. The rectum and the adjacent part of the airbladder are covered with melanophores. A row of 13 clearly defined melanophores extends ventrally along the postanal section of the body. Also, there are small melanophores on the tip of the lower jaw and one is located on the base of the pectoral fin.

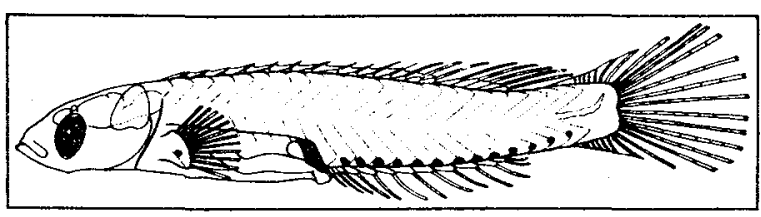

Fig. 7. Scaridae larva, $7.5 \mathrm{~mm}$ SL (Station 310).

Each of the larvae studied has 9 preanal and 16 postanal vertebrae, a characteristic of three genera of Scaridae inhabiting the western North Atlantic (Schultz, 1958), namely, Sparisoma, Cryptotomus and Nicholsina. Because of similarity in meristic features, larvae of these genera are very difficult to differentiate. However, the four larvae noted above are very similar to those of Cryptotomus ustus, described by Regan (1916) and later by Aboussouan (1969).

\section{Family Callionymidae}

\section{Callionymus agassizi Goode and Bean 1888}

1 larva: $6.0 \mathrm{~mm} \mathrm{SL} \mathrm{(7.5} \mathrm{mm} \mathrm{TL)} \mathrm{(sta.} \mathrm{327).}$

The body of this larva is deep (Fig. 8A). The head is large $(\mathrm{HL}=36.6 \% \mathrm{SL})$ and depressed. The eyes are large $(E D=36.4 \% \mathrm{HL})$ and are very close together dorsally (Fig. 8B). The anus is located slightly posterior to the middle of the body (PAL $=55 \% \mathrm{SL}$ ). The air bladder is visible in the upper part of the abdominal cavity. There is a large bifurcated spine on the preoperculum. The dorsal fin has 10 soft rays in front of which are 4 spines (fourth broken). The anal fin has 9 rays, the first being in line with the third soft ray of the dorsal fin. The pectoral fin has 20 rays and its base is large. The ventral fin, with its base below that of the pectoral fin, has a short spine and 5 long, soft rays. The caudal fin consists of 10 principal rays and 5 procurrent rays ( 3 above and 2 below). There are 21 vertebrae, 8 preanal

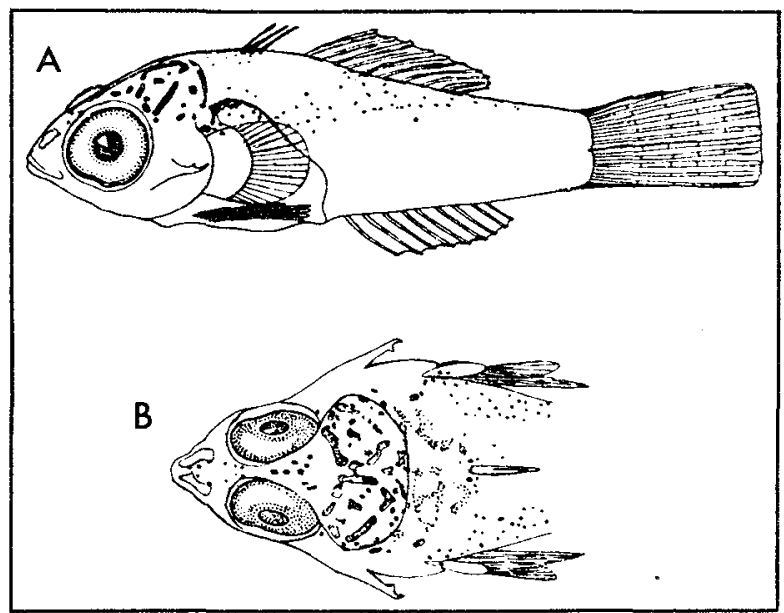

Fig. 8. Callionymus agassizi (A) larva, $6.0 \mathrm{~mm} \mathrm{SL}$, and (B) dorsal view of head (Station 327). 
and 13 postanal. Brown pigmentation occurs mainly on the dorsal parts of the head and the body and on the ventral fins. Intense pigment accumulations on the head form a peculiar design over the hemispheres of the mid-brain. The design is partially repeated behind the brain in the dorsal peritoneum which is transparent through the dorsal tissues (Fig. 8B). Also, pigment cells are present along the anterior margin of the second dorsal spine, one cell is seen on the upper edge of the lobe of the left pectoral fin and two on the lobe of the right pectoral fin.

Larvae of Callionymus from the western North Atlantic have not been described, but the presence of a bifurcated spine on the preoperculum of the larva described above and the numbers of rays in the dorsal and anal fins correspond to $C$. agassizi (Jordan and Evermann, 1896).

\section{Callonymus bairdl Jordan 1887 ?}

1 larva: $5.1 \mathrm{~mm} \mathrm{SL}$ (sta. 310).

The body of this larva is pigmented by branched brown cells. The upper parts of the head and trunk are evenly pigmented with scattered cells. There are 5-6 rows of chromatophores distributed dorsally and 3-4 rows ventrally on the preanal section of the body. The dorsal fin has 3 or 4 spines and 9 or 8 soft rays, and the ventral fin has 1 spine and 4 or 5 soft rays which are short and strongly pigmented. The vertebrate number is 20 or 21 .

The presence of pigment ventrally on the postanal part of the body and the absence of pigment designs on the upper part of the head and adjacent trunk area distinguish this larva from the one described previously. According to the number of soft spines in the dorsal fin, the larva could be related to $C$. bairdi, but identification is tentative because the spines on the preopercula, which would allow identification to the species level, have not yet developed.

\section{Family Gobildae}

\section{Genus ? Species ?}

1 larva: $6.45 \mathrm{~mm}$ SL (sta. 313).

The body is narrow (BD $=16.1 \% \mathrm{SL}$ ) and compressed laterally (Fig. 9). The anus is in the middle of the body ( $\mathrm{PAL}=50.5 \% \mathrm{SL}$ ). The head is long and

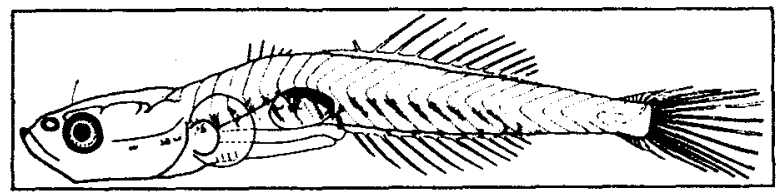

Fig. 9. Gobiidae larva, $6.45 \mathrm{~mm} \mathrm{SL}$ (Station 313). narrow $(\mathrm{HL}=21.3 \% \mathrm{SL})$, and the tip of the lower jaw projects in front of the tip of the upper jaw. The dorsal fin contains 5 spines which are separated from 11 soft rays. The anal fin has 11 rays, and the caudal fin consists of 28 rays (14 principal, 7 superior procurrent and 7 inferior procurrent). There are 24 vertebrae, 9 preanal and 15 postanal. A large airbladder is situated at the level of myomeres 5-10. Pigmentation occurs almost exclusively on the lower part of the body. Large pigment accumulations are distributed along the myosepta of the first 17 myomeres. Several melanophores are located under the edge of postanal myomeres 3-10 and also on myosepta 3-6 of the postanal myomeres. The upper part of the airbladder is strongly pigmented. The tip of the lower jaw is intensely pigmented, and 3 melanophores under the brain are seen through the transparent operculum.

This larva is different from those of Gobiosoma and Microgobius, described by Hildebrand and Cable (1930). It refers to one of the subtropical or tropical species of gobies, with a small number of rays in the dorsal fin and whose larvae have not yet been described. Consequently, larva identification below the family level is not yet possible.

\section{Family Gempylidae}

\section{Diplospinus multistriatus Maul 1948}

1 larva: $4.7 \mathrm{~mm} \mathrm{SL}$ (sta. 320 ).

Larvae of this species were first described by Voss (1954) as Gempylus "A" (Parin, 1967). They have already been found in the Gulf Stream off Nova Scotia (Evseenko and Serebryakov, 1974).

\section{Family Trichiuridae}

\section{Benthodesmus elongatus simonyi (Steindachner 1891)}

1 larva: $20.3 \mathrm{~mm}$ SL (sta. 326).

The larva has a very elongated, laterally compressed and narrow body (Fig. 10). The head is long $(\mathrm{HL}=19.7 \% \mathrm{SL})$ and the eye is relatively large (ED = $18.5 \% \mathrm{HL}$ ). The dorsal fin extends almost the length of

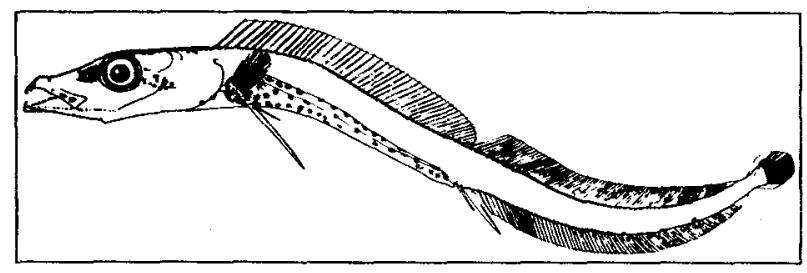

Fig. 10. Benthodesmus elongatus simonyi larva, $20.3 \mathrm{~mm} \mathrm{SL}$ (Station 326) 
the body, with 47 spines anteriorly and $91+$ soft rays posteriorly. The length of the base of the spiny section is slightly less than that containing soft rays. The anal fin has 2 spines and $87+$ soft rays, the former being located under soft ray 2-4 of the dorsal fin. The second anal spine is about twice as long as the first with a smooth edge anteriorly and serrated posteriorly. The pectoral fin has 12 rays, and the ventral fin, located posterior to the base of the pectoral fin, has one long spine serrated at its posterior edge and one short soft ray. The development of soft rays in the dorsal, anal and caudal fins has not yet been completed. The anus is located below the second soft ray of the dorsal fin (PAL $=60.3 \% \mathrm{SL})$. Nostrils are located in front of the eyes, and the mouth is large. On each side of the upper jaw, a large fang is located anteriorly, followed by a small fang which is turned inward, and by 9 small teeth. On each side of the lower jaw, there is a large fang anteriorly, followed by 10-12 small teeth.

A continuous row of melanophores runs along the dorsal margin of the body from the forebrain area to soft ray 72 of the dorsal fin. A similar row extends along the ventral margin of the body from the base of the anal spines to ray 39 of the anal fin and continues after interruption to the base of rays $68-70$, where the last melanophore is the largest in the row. The anterior part of the intestine is covered with a dense concentration of black pigment. The remainder of the intestine and the abdominal cavity are pigmented by large melanophores. A dense concentration of pigment lies directly in front of the eye, there are some pigment cells behind the eye and on the premaxillary, and a continuous row of small melanophores extends along the side of the lower jaw.

Larvae of $B$. elongatus simonyi have not been previously described. However, the designation of the larva described above to this species is beyond doubt because of several characteristic features, e.g. the number of spines in the dorsal fin, the peculiarities of the ventral rays, and the location of the anal spines (Parin and Bekker, 1972). These authors have indicated that distribution is restricted to waters of the North Atlantic.

\section{Family Bothidae}

\section{Citharichthys gymnorhinus Gutherz and Blackman 1970}

\author{
1 larva: $3.6 \mathrm{~mm} \mathrm{SL} \mathrm{(sta.} 343$ ).
}

Larvae of this species have been described by Tucker (1982) and Dowd (MS 1978). C. gymnorhinus has been reported off the Bahamas, Columbia, Florida Keys, Hispaniola, Nicaragua, Panama, Puerto Rico and Tobago (Gutherz and Blackman, 1970), and on the Florida Shelf, off Cuba, Guyana, Venezuela, and the
Virgin Islands (Topp and Hoff, 1972). Larvae of this species have not been previously reported from the open waters of the western North Atlantic.

\section{Bothus ocellatus (Agassiz 1831)}

8 larvae: $4.0 \mathrm{~mm}, 5.5 \mathrm{~mm} \mathrm{SL}$ (sta. 343 ); $5.5 \mathrm{~mm} \mathrm{SL}$ (sta. 320); $6.0 \mathrm{~mm} \mathrm{SL} \mathrm{(sta.} \mathrm{313);} 9.0 \mathrm{~mm} \mathrm{SL} \mathrm{(sta.}$ 330); $9.4 \mathrm{~mm} \mathrm{SL}$ (sta. 374); $9.5 \mathrm{~mm} \mathrm{SL} \mathrm{(sta.} \mathrm{312);}$ $13.0 \mathrm{~mm} \mathrm{SL}$ (sta. 316).

Two of the larvae $(9.4$ and $13.0 \mathrm{~mm})$ have 26 caudal vertebrae and the others have 25. All of the larvae belong to $B$. ocellatus, according to the data of Jutare (MS 1962). Larvae of this species are widely distributed beyond the shelf waters of the North Atlantic and have been found in Gulf Stream eddies (Evseenko, 1976). Also, numerous collections of Bothus sp. have been made on the Scotian Shelf, mostly east of Browns Bank and west of Emerald Bank (Markle et al., 1980).

\section{Family Cynoglossidae}

\section{Symphurus sp.}

1 larva: $11.7 \mathrm{~mm} \mathrm{SL} \mathrm{(sta.} \mathrm{316).}$

It was difficult to determine the species of this larva because of damage to the head and the dorsal fin. However, the pigment pattern is similar to that of $S$. plaguisa larvae (Olney and Grant, 1976). Symphurus larvae have not been previously observed in the open waters of the western North AtInatic, but the report of larvae and juveniles of one species of this genus ( $S$. minor) on the Scotian Shelf (Markle et al., 1980) is evidence that such larvae from southern waters drift northward with the Gulf Stream.

\section{Family Antennariidae}

\section{Histrio histrio (Linnaeus 1758)}

2 larvae: $2.25 \mathrm{~mm} \mathrm{SL}$ (sta. 329); $2.75 \mathrm{~mm} \mathrm{SL}$ (sta. 328).

The larvae of this species have been described by Adams (1960), but there are no data on their distribution. The species inhabits tropical waters of the North Atlantic and the Indo-Pacific (Schultz, 1957). In the western North Atlantic, it may range northward, in association with Gulf Stream water, to Georges Bank (Bigelow and Schroeder, 1953) and even farther northeastward (Leim and Scott, 1966).

\section{Antennarius sp.}

2 larvae: $3.7 \mathrm{~mm} \mathrm{SL} \mathrm{(sta.} \mathrm{336);} 4.0 \mathrm{~mm} \mathrm{SL} \mathrm{(sta.} \mathrm{343).}$

The body is almost ball-like, slightly compressed laterally in the caudal region, and covered evenly with large bifurcated spines. The mouth is large, with smail 
teeth on the lower jaw, and the eyes are large and round. The gill slit, like a round pore, is located under the base of the pectoral fin. Both larvae have rudiments of the ventral fins, and only the soft rays (10-11) are found in the dorsal fin. In both specimens, the anal fin has 7 rays, the pectoral fin 11 rays and the caudal fin 9 rays. The entire body is densely covered with branched, brown pigment cells, with a concentration in the upper part of the peritoneum.

The larvae are very similar to those of Antennarius sp. (5.0 and $5.5 \mathrm{~mm}$ ) from the Indian Ocean (Tsokur, 1972) by the shape and pigmentation of the body and by the shape, size and location of the spines. Identification of the larvae to the species level was difficult because formation of the dorsal fin is incomplete. Also, the paper by Tsokur (1972) is the only one on characteristics of Antennarius larvae inhabiting subtropical and tropical waters.

\section{Conclusions}

Larvae belonging to 22 families of fishes were represented in the ichthyoplankton samples collected in the Slope and Gulf Stream waters off Nova Scotia in November-early December 1974 (Appendix Tables A and B). Larvae of 10 tropical and subtropical families which normally inhabit continental shelf waters were represented by Congridae, Synodontidae, Scorpaenidae, Labridae, Scaridae, Callionymidae, Gobiidae, Bothidae, Cynoglossoidae and Antennariidae; two families of tropical-subtropical epipelagic fishes were represented by larvae of Gempylidae and Trichiuridae; nine families of deep-water fishes were represented by larvae of Gonostomatidae, Sternoptychidae, Melanostomiatidae, Chauliodontidae, Notosudidae, Myctophidae, Bregmacerotidae, Macrouridae and Paralepididae; and the family Scomberesocidae was represented by an egg. Larvae of several species of these families were taken in the waters off eastern Canada for the first time. Myctophid larvae were the most abundant in the samples. However, the quantity of ichthyoplankton was extremely small, as only 98 larvae and one egg were caught during the entire survey.

The surveyed area is a zone of interaction of water masses of different origins - Gulf Stream, Labrador Current and their modifications (Noskov et al., MS 1977). This determines the zoogeographical structure of the ichthyoplankton in the region. In addition to larvae of tropical and subtropical species, the subpolar-temperate $B$. glaciale, the temperate species $N$. rissoi krøyeri, and the temperate to semi-subtropical species $H$. hygomi, $C$. maderensis and $D$. rafinesquii were also found there. Such widely distributed oceanic species as $C$. braueri were also encountered.

Comparison of the data on larval distribution with current patterns and temperature distribution (Noskov

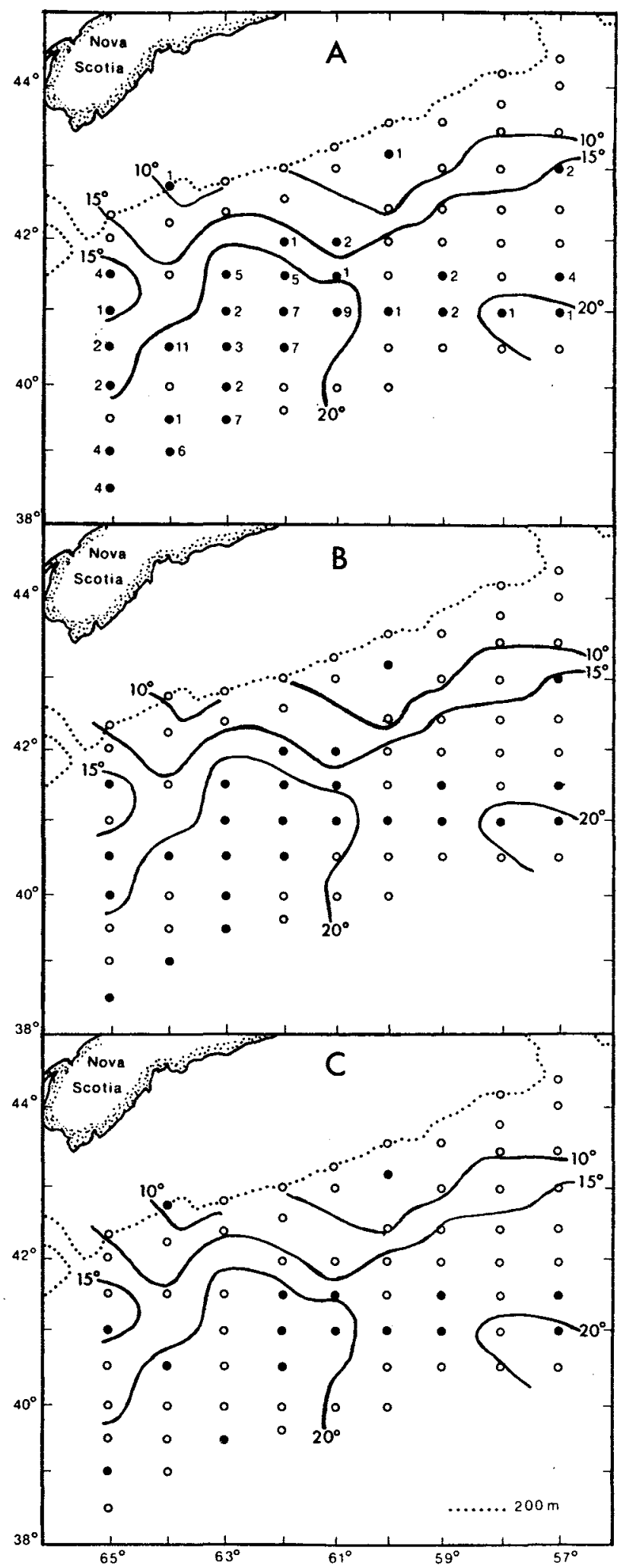

Fig. 11. Distribution of ichthyoplankton in Slope and Gulf Stream waters off Nova Scotia during the survey in late autumn 1974: A, number of specimens caught at each station; B, distribution of larvae of tropical and subtropical shelf species; C, distribution of myctophid larvae. [Closed circles represent positive hauls. Surface temperature isotherms from Noskov et al. (MS 1977).l 
et al., MS 1977) indicates that the majority of larvae (73 of 98 ) were found in meanders of the Gulf Stream, the northern boundary of which approximately coincides with the $20^{\circ} \mathrm{C}$ surface isotherm (Fig. 11A). The majority of the larvae of tropical and subtropical shelf fishes were caught in the area $\left(61^{\circ}\right.$ to $\left.64^{\circ} \mathrm{W}\right)$ where the surface temperature was higher than $20^{\circ} \mathrm{C}$ (Fig. 11B), but some of these species were caught beyond the limits of this meander at significantly lower water temperature: Scaridae and $C$. bairdi at $13.0^{\circ} \mathrm{C}$ (Station 210) and $B$. ocellatus at $15.1^{\circ} \mathrm{C}$ (Station 374). The distribution of myctophid larvae (Fig. 11C) is somewhat more widespread. They were found in the Gulf Stream meanders at $57^{\circ}$ to $58^{\circ} \mathrm{W}$ and $61^{\circ}$ to $64^{\circ} \mathrm{W}$, in the frontal zone where the temperature was $16^{\circ}$ to $18^{\circ} \mathrm{C}$, and in Slope Water less than $10^{\circ} \mathrm{C}$ at Station 323 (C. maderensis) and at Station 352 (B. glaciale).

Larvae of fishes inhabiting the Scotian Shelf were absent in the ichthyoplankton samples. This may be due both to the weak transport of larvae from the shelf to the Gulf Stream zone and to the death of larvae before reaching the zone because of the great difference in temperature $\left(10\right.$ to $\left.15^{\circ}\right)$ of shelf and Gulf Stream waters, according to the temperature conditions during the survey (Noskov et al., MS 1977).

\section{Acknowledgements}

I am grateful to Prof. T. S. Rass for his critical review of the manuscript and to Dr A. M. Pankratov for his kind permission to use the material collected during the Belogorsk survey.

\section{References}

ABOUSSOUAN, A. 1969. Sur une petite collection de larvae de téléostêens récoltée au large du Brésil (campagne Calypso 1962). Vie Milieu (A Biol. Mar.), 20: 595-610.

ADAMS, J. A. 1960. A contribution to the biology and post-larval development of the sargassum fish, Histrio histrio (Linnaeus), with a discussion of the sargassum complex. Bull. Mar. Sci. Gulf Caribb., 10(1): 55-82.

AHLSTROM, E. H., and R. C. COUNTS. 1958. Development and distribution of Vinciguerria lucetia and related species in the eastern Pacific. Fish. Bull., U. S., 58: 363-416.

ANDERSON, W. W. 1957. Early development, spawning, growth and occurrence of the silver mullet (Mugil curema) along the south Atlantic coast of the U. S. Fish. Bull, U. S., 57: 397-414.

ANDERSON, W. W., J.W. GEHRINGER, and F. H. BERRY. 1966. Family Synodontidae. In Fishes of the Western North Atlantic. Mem. Sears Found. Mar. Res., Part 5: 30-102.

BADCOCK, J., and R. C. BAIRD. 1980. Remarks on systematics, devetopment and distribution of the hatchetfish genus Sternoptyx (Pisces, Stomiatoidei). Fish. Bull., U. S., 77: 803-820.

BEEBE, W., and J. CRANE. 1939. Deep-sea fishes of the Bermuda oceanographic expedition. Family Melanostomiatidae. Zoologica (USA), 24(6): 65-238.

BELYANINA, T. N. 1974. Materials on development, taxonomy and distribution of fishes of the family Bregmacerotidae. Proc. Inst. Oceanol. Acad. Sci. USSR, 96: 143-188 (in Russian).
1977. Materials on the development of Chauliodontidae, Osteichthyes. Proc. Inst. Oceanol. Acad. Sci. USSR, 109: 113-132 (in Russian)

BERRY, F. P. 1959. Young jack crevalles (Caranx sp.) off the southeastern Atlantic coast of the U. S. Fish. Bull., U. S., 59: 417-535.

BERTELSEN, E., G. KREFFT, and N. B. MARSHALL. 1976. The fishes of the family Notosudidae. Dana Rep., 86, $300 p$

BIGELOW, H. B., and W. C. SCHROEDER. 1953. Fishes of the Gulf of Maine. Fish. Bull., U. S., 53, 577 p.

BOLIN, R. L. 1959. Iniomi: Myctophidae from the Michael Sars North Atlantic deep-sea expedition, 1910. Rep. M. Sars N. Atlantic Deepsea Exped., 4, Part II, No. 7, 45 p.

CALDWELL, M. C. 1962. Development and distribution of larval and juvenile fishes of the family Mullidae of the western North Atlantic. Fish. Bull., U. S., 62: 403-456.

D'ANCONA, U., and G. CAVINATO. 1965. The fishes of the family Bregmacerotidae. Dana Rep., 64, 93 p.

DOWD, C. E. MS 1978. Abundance and distribution of Bothidae (Pisces, Pleuronectiformes) larvae in the eastern Gulf of Mexico, 1971-72 and 1973. M.Sc. Thesis, Univ. of Miami, Florida, USA, 106 p.

DUDNIK, Y. I., V. K. ZILANOV, V. D. KUDRIN, V. A. NESVETOV, and A. S. NESTEROV. 1981. Distribution and biology of Atlantic saury, Scomberesox saurus (Walbaum), in the Northwest Atlantic. NAFO Sci. Coun. Studies, 1: 23-29.

EGE, V. 1930. Contributions to the knowledge of the North Atlantic and the Mediterranean species of the genus Paralepis Cuv. Rep. Danish Oceanogr. Exped. Medit., 1908-1910, Vol. II (A13), 201 p.

EVSEENKO, S. A. 1976. Larval Bothus ocellatus (Agassiz) in the western North Atlantic. Vopr. Ikhtiol. 16: 661-669 (in Russian).

1982. Eco-morphological peculiarities of the early life history of the flatfishes from the western North Atlantic. Proc. Inst. Oceanol. Acad. Sci. USSR.,118: 43-84 (in Russian).

EVSEENKO, S. A., and V. P. SEREBRYAKOV. 1974. Larval Diplospinus multistriatus Maul (Pisces, Gempylidae) in the Northwest Attantic. Vopr. Ikhtiol., 14: 110-116 (in Russian).

GEHRINGER, J. W. 1959. Early development and metamorphosis of the tenpounder Elops saurus L. Fish. Bull., U. S., 59:619-647.

GREY, M. 1964. Gonostomatidae. In Fishes of the western North Atlantic. Mem. Sears Found. Mar. Res., Part 4: 78-240.

GUTHERZ, E. J., and R. R. BLACKMAN. 1970. Two new species of the flatfish genus Citharichthys (Bothidae) from the western North Atlantic. Copeia, 1970: 340-348.

HILDEBRAND, S. F., and L. E. CABLE. 1930. Development and life history of fourteen teleostean fishes at Beaufort, N. C. Bull. U.S. Bur. Fish., 46: 383-488.

JESPERSEN, P., and A. V. TÅNING. 1926. Mediterranean Sternoptychidae. Rep. Danish Oceanogr. Exped. Medit., 1908-1910, Vol. II (A12), $59 \mathrm{p}$.

JOAKIMSSON, G. MS 1978. On the occurrence and distribution of fish larvae on Georges Bank and Nantucket Shoals in November 1972-1977 (1976 excluded). ICES C.M. Doc., No. L:39.

JORDAN, D. S., and W. B. EVERMANN. 1896. The fishes of North and Middle America. Bull. U. S. Nat. Mus. 47: 1-3136

JUTARE, T.MS 1962. Studies on the biology of Bothus ocellatus with a description of a related new species. M.Sc. Thesis, Univ. of Miami, Florida, USA, $97 \mathrm{p}$.

LEIM, A. H., and W. B. SCOTT. 1966. Fishes of the Atlantic coast of Canada. Bull. Fish. Res. Bd. Canada, 155, 485 p.

MANSUETI, A. J., and J.D. HARDY. 1967. Development of fishes of the Chesapeake Bay region: an atlas of eggs, larval and juvenile stages, Part I. Univ. of Maryland Inst. Nat. Resour., $202 \mathrm{p}$.

MARKLE, D. F., W. B. SCOTT, and A. C. KOHLER. 1980. New and rare records of Canadian fishes and the influence of hydrography on resident and non-resident Scotian Shelf ichthyofauna. Can. J. Fish. Aquat. Sci., 37:49-65.

MARSHALL, N. B., and T. IWAMOTO. 1973. Family Macrouridae. In Fishes of the western North Atlantic. Mem. Sears Found. Mar. Res., Part 6: 496-662

MOSER, H. G., and E. H. AHLSTROM. 1970. Development of lanternfishes (family Myctophidae) in the California Current. Part I. Species with narow-eyed larvae. Bull. Los Angeles County Mus. Nat. 
Hist. Sci. 7, $145 \mathrm{p}$.

1974. Role of larval stages in systematic investigations of marine teleosts: the Myctophidae, a case study. Fish. Bull., U. S., 72: $391-413$

MOSER, H. G., E. H. AHLSTROM, and E. M. SANDKNOP. 1977. Guide to the identification of scorpionfish larvae (family Scorpaenidae) in the eastern Pacific with comparative notes on species of Sebastes and Helicolenus from other oceans. NOAA Tech. Rep., NMFS Circ., 402, $71 \mathrm{p}$.

MUKHACHEVA, V. A. 1974. Cyclothones (genus Cyclothone, family Gonostomatidae) of the world oceans and their distribution. Proc. Inst. Oceanol. Acad. Sci. USSR, 96: 189-254 (in Russian).

NAFPAKTITIS, B. G. 1968. Taxonomy and distribution of the lanternfishes, genera Lobianchia and Diaphus, in the North Atlantic. Dana Rep., 73, $131 \mathrm{p}$.

NAFPAKTITIS, B. G., R. H. BACKUS, J. E. CRADDOCK, R. L. HAEDRICH, D. H. ROBINSON, and C. KARNELLA. 1977. Family Myctophidae. In Fishes of the western North Atlantic. Mem. Sears Found. Mar. Res., Part 7: 13-265.

NESTEROV, A. A., and T. A. SHIGANOVA. 1976. Eggs and larvae of the Atlantic suary, Scomberesox saurus (Walb.) of the North Atlantic. Vopr. Ikhtiol., 16: 315-322 (in Russian).

NOSKOV, A. S., A. M. PANKRATOV, I. K. SIGAEV, and A. I. SHERSTYUKOV. MS 1977. Ecological survey in the Gulf Stream zone southward of Nova Scotia. ICNAFRes. Doc., No. 39, Ser. No. 5064.

OLNEY, J. E., and G. C. GRANT. 1976. Early planktonic larvae of the blackcheek tonguefish, Symphurus plagiusa (Pisces: Cynoglossidae), in the lower Chesapeake Bay. Chesapeake Sci., 17:229-237.

PARIN, N. V. 1967. Materiais on the distribution and biology of the snake mackerel, Gempylus serpens Cuv. (Pisces, Gempylidae), in the Pacific and Indian Oceans. Vopr. Ikhtiol., 7: 990-1000 (in Russian).

PARIN, N. V., and V. E. BEKKER. 1972. Materials on taxonomy and distribution of some trichiuroid fish (Pisces, Trichiuroidae, Scombrolabracidae, Gempylidae, Trichiuridae). Proc. Inst. Oceanol. Acad. Sci. USSR, 93: 110-204 (in Russian).

PERTSEVA-OSTROUMOVA, T. A. 1974. New data on lantern-fish larvae (Pisces, Myctophidae) with oval eyes from the Indian and Pacific Oceans. Proc. Inst. Oceanol. Acad. Sci. USSR, 96: 77-142 (in Russian).

POWLES, H. 1979. Larval distribution and recruitment hypotheses for snappers and groupers of the South Atlantic Bight. Proc. Annu. Conf. Southeast. Assoc. Game Fish Comm., 31: 362-371.

RASS, T.S. 1949. The composition of the ichthyofauna of the Barents
Sea and fish larvae of this area. Trudy VNIRO, 17: 7-67 (in Russian).

REGAN, C. T. 1916. Larval and post-larval fishes. British Antarctic Terra Nova expedition, 1910. Nat. Hist. Rep. Zool., Vol. I(4): 125156.

ROFEN, R. R. 1966. Family Paralepididae. In Fisheis of the western North Atlantic. Mem. Sears Found. Mar. Res., Part 5: 205-461.

RUDOMYETKINA, G. P. 1980. Larvae of lizard-head fish (family Synodontidae), from the Central-Tropical Atlantic. Vopr. Ikhtiol., 20 557-561 (in Russian).

SCHULTZ, L. P. 1957. The frogfishes of the family Antennariidae. Proc. U. S. Nat. Mus., 107: 47-105.

1958. Review of the parrotfishes (family Scaridae). Bull. U.S. Nat. Mus., 214, 143 p.

1961. Revision of the marine silver hatchetfishes (family Sternoptychidae). Proc. U. S. Nat. Mus., 112: 587-649.

SMITH, D. G. 1979. Guide to the Leptocephati (Elopiformes, AnguilIformes, and Notacanthiformes). NOAA Tech. Rep., NMFS Circ. 424, $39 \mathrm{p}$

SMITH, W. G., J. D. SIBUNKA, and A. WELLS. 1975. Seasonal distributions of larval flatfishes (Pleuronectiformes) on the continental shelf between Cape Cod, Massachusetts, and Cape Lookout, North Carolina, 1965-66. NOAA Tech. Rep., NMFS Circ., SSRF-691, $68 \mathrm{p}$.

TÅNiNG, A. V. 1918. Mediterranean Scopelidae (Saurus, Aulopus, Chlorophthalmus and Myctophum). Rep. Danish Oceanogr. Exped. Medit., 1908-1910, Vol. II (A7), 154 p.

TOPP, R. W., and F. N. HOFF. 1972 Flatfishes (Pleuronectiformes). Memoir Hourg. Cruises, Vol. IV, Part II, 135 p.

TSOKUR, A. G. 1972. Larval frogfish (Antennarius sp., Lophiiformes, Pisces) from the Indian Ocean. Vopr. Ikhtiol., 12: 186-188 (in Russian).

TUCKER, J.W. 1982. Larval development of Citharichthys cornutus, $C$. gymnorhinus, C. spilopterus, and Etropus crossotus (Bothidae), with notes on larval occurrence. Fish. Bull., U. S., 80: 35-73.

VOSS, N. A. 1954. The postlarval development of the fishes of the family Gempylidae from the Florida Current. 1. Nesiarchus Johnson and Gempylus Cuv. and Val. Bull. Mar. Sci. Gulf Caribb., 4(2): 120-147.

WITZELL, W. N. 1973. Gonostomatidae. In Checklist of the fishes of the northeastern Atlantic and of the Mediterranean, J. C. Hureau and T. Monod (eds.), UNESCO, Paris, p. 114-122.

YAKUBOVSKY, M. 1970. Methods of staining of the lateral line system and bone formation in fish. Zool. Zh., 49; 1398-1402 (in Russian). 


\section{APPENDIX}

TABLE A. Stations where ichthyoplankton were found during Belogorsk cruise, 1974.

\begin{tabular}{|c|c|c|c|}
\hline \multirow[b]{2}{*}{ Date } & \multirow{2}{*}{$\begin{array}{c}\text { Station } \\
\text { No. }\end{array}$} & \multicolumn{2}{|c|}{ Position } \\
\hline & & Lat. & Long. \\
\hline \multirow[t]{2}{*}{$14 \mathrm{Nov}$} & 310 & $41^{\circ} 30^{\prime}$ & $65^{\circ} 00^{\prime}$ \\
\hline & 311 & $40^{\circ} 59^{\prime}$ & $65^{\circ} 00^{\prime}$ \\
\hline \multirow[t]{4}{*}{15 Nov } & 312 & $40^{\circ} 30^{\prime}$ & $65^{\circ} 00^{\prime}$ \\
\hline & 313 & $40^{\circ} 00^{\prime}$ & $65^{\circ} 00^{\prime}$ \\
\hline & 315 & $39^{\circ} 00^{\prime}$ & $65^{\circ} 00^{\prime}$ \\
\hline & 316 & $38^{\circ} 30^{\prime}$ & $65^{\circ} 00^{\prime}$ \\
\hline \multirow[t]{3}{*}{$16 \mathrm{Nov}$} & 317 & $39^{\circ} 00^{\prime}$ & $64^{\circ} 00^{\prime}$ \\
\hline & 318 & $39^{\circ} 30^{\prime}$ & $64^{\circ} 00^{\prime}$ \\
\hline & 320 & $40^{\circ} 30^{\prime}$ & $64^{\circ} 00^{\prime}$ \\
\hline $17 \mathrm{Nov}$ & 323 & $42^{\circ} 47^{\prime}$ & $64^{\circ} 00^{\prime}$ \\
\hline \multirow[t]{3}{*}{$18 \mathrm{Nov}$} & 326 & $41^{\circ} 30^{\prime}$ & $63^{\circ} 00^{\prime}$ \\
\hline & 327 & $41^{\circ} 00^{\prime}$ & $63^{\circ} 00^{\prime}$ \\
\hline & 328 & $40^{\circ} 30^{\prime}$ & $63^{\circ} 00^{\prime}$ \\
\hline \multirow[t]{2}{*}{$19 \mathrm{Nov}$} & 329 & $40^{\circ} 00^{\prime}$ & $63^{\circ} 00^{\prime}$ \\
\hline & 330 & $39^{\circ} 30^{\prime}$ & $63^{\circ} 00^{\prime}$ \\
\hline \multirow[t]{4}{*}{$20 \mathrm{Nov}$} & 333 & $40^{\circ} 30^{\prime}$ & $62^{\circ} 00^{\prime}$ \\
\hline & 334 & $41^{\circ} 00^{\prime}$ & $62^{\circ} 00^{\prime}$ \\
\hline & 335 & $41^{\circ} 30^{\prime}$ & $62^{\circ} 00^{\prime}$ \\
\hline & 336 & $41^{\circ} 59^{\prime}$ & $61^{\circ} 59^{\prime}$ \\
\hline \multirow[t]{3}{*}{$22 \mathrm{Nov}$} & 341 & $42^{\circ} 00^{\prime}$ & $61^{\circ} 00^{\prime}$ \\
\hline & 342 & $41^{\circ} 30^{\prime}$ & $61^{\circ} 00^{\prime}$ \\
\hline & 343 & $41^{\circ} 00^{\prime}$ & $61^{\circ} 00^{\prime}$ \\
\hline \multirow[t]{2}{*}{$25 \mathrm{Nov}$} & 348 & $41^{\circ} 00^{\prime}$ & $60^{\circ} 00^{\prime}$ \\
\hline & 352 & $43^{\circ} 10^{\prime}$ & $60^{\circ} 00^{\prime}$ \\
\hline \multirow[t]{2}{*}{$28 \mathrm{Nov}$} & 358 & $42^{\circ} 00^{\prime}$ & $59^{\circ} 00^{\prime}$ \\
\hline & 359 & $41^{\circ} 30^{\prime}$ & $59^{\circ} 00^{\prime}$ \\
\hline \multirow[t]{2}{*}{$29 \mathrm{Nov}$} & 360 & $41^{\circ} 00^{\prime}$ & $59^{\circ} 00^{\prime}$ \\
\hline & 363 & $41^{\circ} 00^{\prime}$ & $58^{\circ} 00^{\prime}$ \\
\hline \multirow[t]{3}{*}{$2 \mathrm{Dec}$} & 374 & $43^{\circ} 00^{\prime}$ & $57^{\circ} 00^{\prime}$ \\
\hline & 377 & $41^{\circ} 30^{\prime}$ & $57^{\circ} 00^{\prime}$ \\
\hline & 378 & $41^{\circ} 00^{\prime}$ & $57^{\circ} 00^{\prime}$ \\
\hline
\end{tabular}

TABLE B. List of families, species, number of larvae and station numbers relevant to the ichthyoplankton survey off Nova Scotia in late autumn, 1974.

\begin{tabular}{lcc}
\hline \multicolumn{1}{c}{ Family/Species } & $\begin{array}{c}\text { Number of } \\
\text { specimens }\end{array}$ & $\begin{array}{c}\text { Station } \\
\text { numbers }\end{array}$ \\
\hline $\begin{array}{l}\text { Congridae } \\
\text { Gnathophis bothytopos }\end{array}$ & 1 & 326 \\
Gonostomatidae & 2 & 312,359 \\
$\quad \begin{array}{l}\text { Vinciguerria poweriae } \\
\text { Gonostoma elongatum }\end{array}$ & 3 & $315,317,320$ \\
$\quad$ Cyclothone braueri & 1 & 329 \\
$\begin{array}{l}\text { Sternoptychidae } \\
\quad \text { Sternoptyx diaphana }\end{array}$ & 1 & 310 \\
Melanostomiatidae \\
$\quad$ Genus? Species?
\end{tabular}

TABLE B. (continued).

\begin{tabular}{|c|c|c|}
\hline Family/Species & $\begin{array}{l}\text { Number of } \\
\text { specimens }\end{array}$ & $\begin{array}{c}\text { Station } \\
\text { numbers }\end{array}$ \\
\hline \multicolumn{3}{|l|}{ Synodontidae } \\
\hline Trachinocephalus myops & 1 & 343 \\
\hline \multicolumn{3}{|l|}{ Notosudidae } \\
\hline Scopelosaurus sp. & 1 & 374 \\
\hline Scopelosaurus mauli & 7 & $\begin{array}{c}320,333,334 \\
335,377\end{array}$ \\
\hline \multicolumn{3}{|l|}{ Myctophidae } \\
\hline Hygophum macrochir & 1 & 317 \\
\hline Hygophum hygomi & 8 & $\begin{array}{l}317,330,333 \\
335,343,360\end{array}$ \\
\hline Hygophum reinhardtii & 1 & 359 \\
\hline Benthosema glaciale & 2 & 333,352 \\
\hline Diogenichthys atlanticus & 3 & $311,330,377$ \\
\hline Myctophum nitidulum & 1 & 318 \\
\hline Myctophum selenops? & 1 & 334 \\
\hline Notolychnus valdiviae & 1 & 378 \\
\hline Diaphus rafinesquii & 3 & $315,320,335$ \\
\hline Diaphus sp. & 1 & 317 \\
\hline Bolinichthys indicus & 1 & 343 \\
\hline Ceratoscopelus maderensis & 4 & $317,320,323$ \\
\hline Ceratoscopelus warmingii & 1 & 360 \\
\hline \multicolumn{3}{|l|}{ Paralepididae } \\
\hline Notolepis rissoi krфyeri & 3 & $310,358,377$ \\
\hline \multicolumn{3}{|l|}{ Scomberesocidae } \\
\hline Scomberesox saurus & 1 & 333 \\
\hline \multicolumn{3}{|l|}{ Bregmacerotidae } \\
\hline Bregmaceros macclellandi & 2 & 326,335 \\
\hline \multicolumn{3}{|l|}{ Macrouridae } \\
\hline Genus? Species & 1 & 326 \\
\hline \multicolumn{3}{|l|}{ Scorpaenidae } \\
\hline Scorpaena sp.? & 1 & 317 \\
\hline \multicolumn{3}{|l|}{ Labridae } \\
\hline Genus? Species? & 1 & 328 \\
\hline \multicolumn{3}{|l|}{ Scaridae } \\
\hline Genus? Species? & 4 & $\begin{array}{l}310,327 \\
330,333\end{array}$ \\
\hline \multicolumn{3}{|l|}{ Callionymidae } \\
\hline Callionymus agassizi & 1 & 327 \\
\hline Callionymus bairdi? & 1 & 310 \\
\hline \multicolumn{3}{|l|}{ Gobiidae } \\
\hline Genus? Species? & 1 & 313 \\
\hline \multicolumn{3}{|l|}{ Gempylidae } \\
\hline Diplospinus multistriatus & 1 & 320 \\
\hline \multicolumn{3}{|l|}{ Trichiuridae } \\
\hline Benthodesmus elongatus simonyi & 1 & 326 \\
\hline \multicolumn{3}{|l|}{ Bothidae } \\
\hline Citharichthys gymnorhinus & 1 & 343 \\
\hline Bothus ocellatus & 8 & $\begin{array}{c}312,313,316,320 \\
330,343,374\end{array}$ \\
\hline \multicolumn{3}{|l|}{ Cynoglossidae } \\
\hline Symphurus sp. & 1 & 316 \\
\hline \multicolumn{3}{|l|}{ Antennariidae } \\
\hline Histrio histrio & 2 & 328,329 \\
\hline Antennarius sp. & 2 & 336,343 \\
\hline
\end{tabular}

